\title{
Kontroversi Ulama Kontemporer Tentang Keberadaan Bank ASI
}

\author{
Zulhamdi \\ zoel_hamdi@yahoo.co.id \\ Fakultas Syariah, Institut Agama Islam Negeri Lhokseumawe
}

\begin{abstract}
The position of the mother who is breastfeeding a baby is the same status as her mother because she is not allowed to marry the woman and her offspring. In Islam, it is called brotherhood. The problem now is milk stored in the ASI Bank which can be used by a baby at any time, how is the law in an Islamic perspective, giving rise to khilafiah among scholars related to the existence of the ASI bank. This study uses a descriptive qualitative research approach, namely document review. Controversial scholars related to the existence of ASI banks. Some scholars allow ASI banks because babies who drink milk from breast milk banks cannot become mahram for women who have breast milk. After all, the prohibited breastfeeding is if they breastfeed directly to suck the nipples of women who have breast milk. Breast milk, like a baby child who suckles his mother directly. Whereas scholars who refuse the existence of ASI bank their reason is that it will cause mixing of nasab, because forbidden milking can occur with the entry of milk into the baby's stomach, even without direct breastfeeding, like a baby who is breastfeeding at his mother directly.
\end{abstract}

\section{Keyword: Controversy, Contemporary Ulama, Bank Breast Milk}

Abstrak. Kedudukan ibu yang menyusui seorang bayi, sama statusnya dengan ibu kandung sendiri, dikarenakan tidak boleh menikahi wanita tersebut beserta dengan keturunannya. Dalam Islam disebut saudara sepersusuan. Yang jadi permasalahan sekarang ini adalah air susu yang tersimpan di Bank ASI yang kapan saja dapat dimanfaatkan oleh seorang bayi, bagaimanakah hukumnya dalam perspektif Islam, sehingga menimbulkan khilafiah di kalangan ulama terkait dengan keberadaan bank ASI. Penelitian ini menggunakan pendekatan penelitian kualitatif deskriptif, yaitu penelaahan dokumen. Kontroversial ulama terkait dengan keberadaan bank ASI, Ada sebagian ulama membolehkan Bank ASI dengan alasan bayi yang meminum air susu dari bank ASI tidak bisa menjadi mahram bagi wanita yang mamiliki ASI tersebut, karena susuan yang mengharamkan adalah jika dia menyusui langsung menghisap puting payudara wanita yang mempunyai ASI, seperti halnya seorang anak bayi yang menyusu ibunya lansung. Sedangkan ulama yang menolak keberadaan bank ASI alasan mereka adalah akan mengakibatkan bercampurnya nasab, karena susuan yang mengharamkan bisa terjadi dengan masuknya susu ke dalam perut bayi tersebut, walaupun tanpa menyusui langsung, seperti seorang bayi yang menyusu pada ibunya lansung

\section{Keyword: Kontroversi, Ulama Kontemporer, Bank ASI}

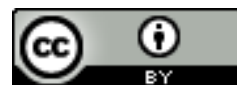




\section{PENDAHULUAN}

Seorang bayi sah-sah saja menyusui kepada perempuan lain, sekiranya air susu ibunya tidak ada atau tidak mencukupi, sehingga ibu kandungnya sendiri tidak dapat menyusuinya. Rasulullah SAW sendiri juga pernah menyusui pada Halimatus Sa'diyah untuk dipelihara dan dididiknya. (Ali Hasan, 1997) Kedudukan ibu yang menyusui seorang bayi, sama statusnya dengan ibu kandung sendiri, dikarenakan tidak boleh menikahi wanita tersebut beserta dengan keturunannya. Dalam Islam disebut saudara sepersusuan. Kejadian yang pernah dialami Rasulullah di atas jelas, siapa perempuan yang menyusui dan siapa bayi yang disusui itu. Sehinga implikasi hukumnya juga jelas disamakan dengan mahram. Yang jadi permasalahan sekarang ini adalah air susu yang tersimpan di Bank ASI yang kapan saja dapat dimanfaatkan oleh seorang bayi, bagaimanakah hukumnya dalam perspektif Islam? Menurut Perspektif Imad Zaki Al-Barudi mengatakan bahwa dibolehkan mengambil ASI dari Bank ASI apabila dalam keadaan terpaksa. Akan tetapi selagi ibu kandung masih memungkinkan menyusui anaknya, maka itulah yang terbaik. Karena kontak kebathinan antara si bayi dengan ibunya akan terjalin juga dengan mesra pada saat menyusui bayi tersebut. Berbeda halnya apabila air susu yang diminum anaknya itu berasal dari perempuan lain. ( Imad Zaki Al-Barudi, t.th).

Sejak adanya Bank ASI, sebagian ulama mengkritisinya dengan membuat penelitian-penelitian dan diskusi terkait keberadaan bank ASI. Menurut fatwa MUI dalam Musyawarah Nasional (Munas) MUI ke VIII di Hotel Twin Plaza, Jakarta Barat pada tahun 2010 menyatakan bahwa mengambil susu dari Bank ASI diperbolehkan dengan persyaratan operasionalnya sebagai berikut: Syarat pertama adalah adanya musyawarah antara orang tua bayi dan donor yang termasuk pembahasan mengenai biaya bagi donor. Musyawarah antara kedua belah pihak dibutuhkan karena anak yang menyusu dari ibu yang sama akan menjadi saudara sesusuan yang haram hukumnya untuk menikah. Jika orang tua bayi mengetahui siapa pendonor ASI yang digunakan maka dapat dihindari pernikahan antara saudara sesusuan yang diharamkan oleh agama Islam. Syarat 
lain dibolehkannya mendonorkan ASI pada Bank ASI tersebut adalah donor harus dalam kondisi sehat dan tidak hamil selama memberikan ASI-nya serta para donor juga harus tetap menjaga syariat Islam dalam perilaku sehari-hari, berdasarkan permasalahan di atas menggugah penulis melakukan penelitian tentang kontroversi ulama kontemporer terkait keberadaan Bank ASI.

\section{METODE PENELITIAN}

Metode penulisan ini merupakan studi penelitian dengan cara menelaah sejumlah buku-buku, membuka web untuk memperoleh data teori dan konsep yang berhubungan dengan pembahasan ini dengan menggunakan metode dan teknik pengumpulan data tersebut kiranya dapat terkumpul seluruh data yang dibutuhkan untuk mendukung penulisan jurnal ini.

\section{HASIL PENELITIAN}

\section{PERSPEKTIF ULAMA KONTEMPORER MENGENAI KEBERADAAN BANK ASI}

\section{A. Bank ASI}

Bank ASI adalah tempat pengumpulan, penyimpanan ASI dari donor ASI yang selanjutnya akan disalurkan kepada ibu-ibu yang mebutuhkan ASI kepada bayinya. Bagi Ibu yang sehat serta memiliki kelebihan ASI bisa mendonorkan ASI nya ke Bank ASI. ASI biasanya disimpan di dalam wadah plastik, dan kemudian didinginkan dalam lemari pendingin agar tidak terkontaminasi oleh bakteri. Bagi para ibu yang kesulitan memberikan ASI untuk anaknya menjadi solusi untuk didirikannya Bank ASI (Mahjuddin, 2003). Bank ASI pertama dikenal dan berkembang di benua Amerika, tepatnya Amerika Serikat, Kanada dan Meksiko, dan Asosiasinya telah berdiri mulai tahun 1985 dengan nama The Human Milk Banking Association of North America(HMBANA). Asosiasi tersebut bertujuan untuk menyediakan panduan bagi pelaksanaan, pendidikan, serta penelitian terkait Bank ASI di Amerika Serikat, Meksiko dan Kanada. Asosasi merupakan kelompok penyedian layanan kesehatan yang bersifat multidisipliner yang mendukung, 
menjaga, dan mempromosikan Bank ASI dan menjadi agen antara Bank ASI dengan institusipemerintah. yang beranggotakan 11 Bank ASI dalam asosiasi tersebut.

Keberadaan Asosiasi Bank ASI di Amerika Utara merupakan salah satu bukti bahwa bank ASI telah berkembang pada tahun 1980 an yang selanjutnya mengalami perkembangan pesat pada tahun 1990 an. Yan kemudian HMBANA membuat prosedur penanganan donor ASI. Seperti menjaga kualitas ASI dari pendonor sampai kepada yang membutuhkan. Adapun langkah-langkah yang ditempuh adalah:

a. Melakukan Identifikasi, dan screening donor, termasuk riwayat penyakit dan juga tes darah pendonor.

b. Susu yang dikirimkan kepada bank ASI harus dalam kondisi membeku

c. Susu tersebut kemudian dicairkan dan dicampurkan dengan susu dari pendonor lainnya

d. Susu disterilkan pada suhu $62,5^{\circ} \mathrm{C}$ selama setengah jam

e. Bakteriyang bermanfaat dibiakkan sajauntuk menjamin hasilsterilisasi

f. Menganalisis kandungan susu, seperti karbohidrat, laktos dan lemak.

g. Susu yang steril dibekukan pada suhu $20^{\circ} \mathrm{C}$.

h. Baru kemudian susu tersebut disalurkan sesuai dengan resep dokter.

Biaya yang dikenakan sesuai dengan biaya proses dan pengiriman. Pendonor tidak memperoleh ganti uang. Praktek screening dan tes darah rutin bagi pedonor juga dipraktekkan di Norwegia. Pendonor setiap tiga bulan dites dari kemungkinan terjangkit virus HIV, Hepatitis B dan C, CMV, dan virusleukimia(HTLV)ldan2. Bank ASI harus memiliki sistem untuk melacak arus donor susu dari pedonor kepada penerima, namun Bank ASI merahasiakan identitas pendonor dan penerima. (Anne Hagen Grøvslien and Morten Gronn, 2009)

Sejauh ini,ASI yang terkumpul dan disalurkan oleh bank ASI berasal dari donor dengan akad hibah. Namun tidak menutup kemungkinan bahwa bank ASI beroperasi dengan sistem jual beli ketika kebutuhan terhadap bank ASI makin banyak dan menjadi lahan bisnis bagi pengusaha besar. Berbagai permasalahan tersebut menuntut jawaban dari kalangan muslim agar praktik bank ASI tidak menimbulkan dampakmoral dan hukum bagiumat Islam. 


\section{B. Hukum Keberadaan Bank ASI}

Bahwa di dalam kebolehan menjual ASI itu ada kemungkaran karena bisa menimbulkan rusaknya perkawinan yang disebabkan nikahnya orang sepersusuan dan hal tersebut tidak bisa diketahui jika antara lelaki dengan wanita yang menikah telah meminum ASI yang dijual pada bank ASI yang pendonornya sama tersebut. (Masjfuk Zuhdi, 2000), akan tetapi, ada juga yang berpendapat kebalikannya yaitu menjual ASI memberikan faedah bagi manusia yaitu dengan tercukupinya gizi bagi bayi karena banyak bayi yang tidak memperoleh ASI yang cukup baik karena penyakit yang diderita sang ibu ataupun karena kesibukan sang ibu tersebut untuk menyusui anaknya. Akan tetapi pendapat tersebut juga dapat ditolak karena kemudharatan yang timbul lebih besar dari manfaatnya yang diperoleh, yaitu terjadinya percampuran nasab. Padahal Islam menganjurkan kepada manusia untuk selalu menjaga nasabnya. Sebagaimana kaidah ushul yang menyebutkan bahwa:

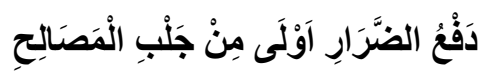

Menolak kemadharatan lebih utama dari pada menarik kemaslahatan.

Ibnu Sayuti menyebutkan di dalam kitab Asybah Wa Nadhaair bahwa di dalam kaidah ushul disebutkan bahwa di antara prinsip dasar Islam adalah :

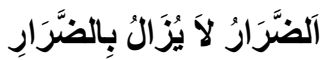

Kemudharatan itu tidak dapat dihilangkan dengan kemudharatan lagi.

Hal ini jelas, karena akan melahirkan permasalahan baru. Yang berkaitan dengan permasalahan ini yaitu, ketiadaan ASI bagi seorang bayi adalah suatu kemudharatan, maka memberi bayi dengan ASI yang dijual di bank ASI adalah kemudharatan baru. Maka apa yang tersisa dari bertemunya kemudharatan kecuali kemudharatan. (Masjfuk Zuhdi, 2000)

Ada sebagian ulama kontemporer yang membolehkan keberadaan bank ASI, di antaranya adalah Yusuf al-Qardhawi. Mereka beralasan:

a. Bahwa kata kata radha' (menyusui) di dalam bahasa Arab bermakna menghisap puting payudara secara lansung dan meminum ASI nya. Maka oleh karena itu jika meminum ASI bukan menghisap lansung puting payudara 
maka tidak disebut menyusui, maka efek yang ditimbulkan dari minum susu tersebut tidak berpengaruh terhadap hukum nasab.

b. Yang mengakibatkan adanya saudara sepersusuan adalah sifat "keibuan", yang ditegaskan di dalam $\mathrm{Al}$-Qur'an tersebut tidak akan terbentuk hanya sematamata diambilkan air susunya, tetapi karena proses menghisap puting payudaranya dan selalu melekat padanya sehingga melahirkan kasih sayang si ibu dan ketergantungan si anak. Dari keibuan ini maka muncullah persaudaraan sepersusuan. Jadi, keibuan ini merupakan asal (pokok), sedangkan yang lain mengikutinya.

c. Pendapat yang disampaikan oleh beberapa kalangan madzhab dimana mereka memberi ketentuan berapa kali penyusuan terhadap seseorang sehingga antara bayi dan ibu susu memilki ikatan yang diharamkan nikah, mereka mengatakan bahwa jika si bayi hanya menyusu kurang dari lima kali susuan maka tidaklah membawa pengaruh di dalam hubungan darah. (Cholil Uman, 2000)

\section{Persoalan yang ditimbulkan oleh keberadaan Bank ASI}

Adapun persoalan yang ditimbulkan terkait keberadaan bank ASI tersebut adalah persoalan radhā’ah, persoalan muamalah: jual beli dan hibah.

\section{a. Raḍā'ah}

Hal yang paling utama yang terkait langsung dengan persoalan bank ASI

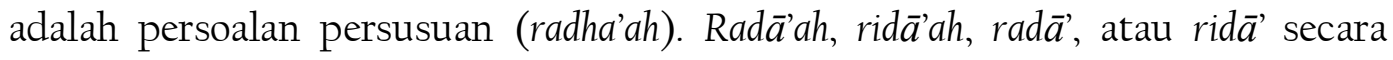
bahasa, menurut Jalal al-Din al-Suyuti adalah: Istilah (yang menunjuk) pada menghisap payudara dan meminum susu darinya (Jalal al-Din al-Suyuth, tt.h). Pengertian radā'ah secara bahasa tersebut menegaskan bahwa persusuan terjadi secara langsung oleh bayi yang menghisap puting payudara ibu, sehingga meminumkan susu yang telah dipisahkan (disedot) dari ibu secara lughawi tidak disebut dengan radä’ah. (Abdurrahman al-Jazary, 2001)

Namun pengertian radha'ah menurut syara' berkembang secara lebih luas. Menurut istilah, al-Suyuthi mendefinisikan radha'ah dengan Istilah yang menunjuk 


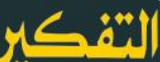

pada sampainya susu dari seorang perempuan atau benda yang dihasilkan dari susu tersebut ke dalam perut atau otak/sumsum anak-anak. Definisi serupa juga disampaikan oleh Abdurrahman al-Jaziry. Yang menyebutkan bahwa radha'ah adalah: Sampainya susu manusia ke rongga anak yang usianya tidak lebih dari dua tahun (Abdurrahman al-Jazary, 2001).

Penjelasan al-Jaziry ini memberikan penjelasan yang lebih khusus mengenai persusuan yang mengakibatkan implikasi hukum, yaitu susu manusia yang masuk ke dalam perut bayi yang usianya belum sampai dua tahun. persyaratan usia dua tahun sebagai batas sepersusuan yang berdampak implikasi hukum merupakan hasil pemahaman dalil dan berdasarkan mafhum (makna tidak langsung) dari al-Qur'an, yang didukung oleh dalil hadis lainnya, seperti haknya hadis yang diriwayatkan oleh Turmudzi: Tidak ada persusuan kecuali yang membuat usus terbuka (kenyang), yaitu sebelum usia dua tahun (HR al-Tirmidzi dan dihasankan olehnya).

Seperti hadis perintah Rasulullah s.a.w agar menyusui Salim kepada Sahlah binti Suhail, meskipun salim pada saat itu sudah berusia baligh agar bebas masuk ke rumah sebagaimana mahram dipandang sebagai dalil yang dinasakh atau dalil yang marjuh (dikalahkan). (Mustafa Dib al-Bigha, t.th). Definisi alSuyuthi dan Abdurrahman al-Jaziry mengenai persusuan di atas dapat dilacak akarnya dari pemahaman mengenai persusuan dalam fikih Islam. Abu Zakariya Yahya al-nawawi, misalnya, memetakan mengenai elemen (rukun) persusuan. AlNawawi melakukan pemetaan kepada tiga elemen persusuan, yaitu 1) orang yang menyusui, 2) susu, 3) tempat susu itu masuk.

Elemen pertama, yaitu orang yang menyusui dikhususkan lebih lanjut oleh al-Nawawi dengan tiga syarat: a) perempuan, b) hidup, dan c) sudah mungkin melahirkan. Elemen kedua, yaitu susu tidak harus disyaratkan susu yang telah terpisah dari payudara itu harus tetap berbentuk susu, melainkan bisa berubah dalam wujud lain atau bahkan bercampur dengan benda lain.

Berbeda pendapat dengan apa yang disampaikan oleh Sayyid Sabiq. Yang berpendapat bahwa persusuan yang mengakibatkan terjadinya pengharaman 
(dalam pernikahan) akibat terjadinya hubungan persaudaraan adalah persusuan yang sempurna, yaitu persusuan yang terjadi dengan bayi lansung menyusu ke payudara ibu. (Sayyid Sabiq, 1983) Elemen ketiga, yaitu tempat susu masuk, dispesifikasi oleh al-Nawawi dengan tiga syarat: a) perut, b) anak kecil yang kurang dari dua tahun, c) masih hidup. (Taqi al-Din al-Husayni, t.th)

Menurut hukum syara', persusuan merupakan hak bagi bayi dan anjuran bagi ibu. Akan tetapi kewajiban tersebut tidak bersifat mutlak karena persusuan tersebut juga bisa dilakukan oleh perempuan selain ibu.

\section{1) Persusuan oleh ibu}

Persusuan oleh ibu kandung sangat dianjurkan dalam al-Qur'an, sebagaimana firman Allah dalam surat al-Baqarah (233) yang artinya: Para Ibu hendaklah menyusui anaknya selama dua tahun penuh, bagi yang ingin menyempurnakan penyusuannya.

Dalil di atas menjelaskan bahwa menyusui anak adalah anjuran, namun bukan kewajiban. Berarti bahwa ibu boleh saja tidak menyusui anaknya, meskipun hal tersebut bermakna tidak melakukan yang lebih utama. Kebiasaan persusuan oleh ibu kandung juga terdapat dalam al-Quran surat al-Ahqaf ayat 15, yang artinya berbunyi: Kami perintahkan kepada manusia supaya berbuat bagi kepada kedua orang tuanya. Ibunya mengandungnya dengan susah payah. Ia mengandungnya dan menyapihnya selama tiga puluh bulan. Ayat tersebut menjelaskan bahwa anak diperintahkan supaya menghormati kedua orang tuanya, terkhusus ibu. Karena Ibu menyapih dan mengandungnya selama 30 bulan.

\section{2) Persusuan oleh perempuan selain ibu}

Persusuan oleh selain ibu kandung telah dipraktekkan oleh Rasulullah sendiri ketika kecil disusui oleh Halimah al-Sa'diyah. Rasulullah sendiri mengisyaratkan pengakuan terhadap persusuan oleh perempuan selain ibu, sebagaimana tampak dalam hadits berikut: Riwayat dari Ibnu Abbas R.A. bahwa Nabi SAW dikehendaki untuk menikah dengan anak Hamzah, beliau menjawab: Dia (anak Hamzah) haram bagiku karena dia anak saudara sususuanku. Diharamkan karena persusuan sebagaimana diharamkan karena hubungan darah (nasab).

Jurnal At-Tafkir: Volume 13 Nomor 1 Tahun 2020

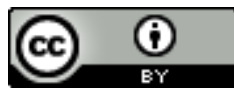

This work is licensed under a Creative Commons Attribution 4.0 International License 
Hadis tersebut di atas mengemukakan mengenai perjodohan Rasulullah dengan anak Hamzah, paman Rasulullah, yang ditolak oleh Rasulullah. Beliau menolak karena Hamzah, meskipun paman Rasulullah, tetapi juga saudara sepersusuannya. Rasulullah pernah disusui oleh Tsaubah, hamba Abu Lahab, yang sebelumnya juga pernah menyusui Hamzah. (Muhammad bin Ismail alKahlani al-Shan'ani, t.th) permasalahan tersebut juga menjelaskan bahwa Rasulullah mengakui dan menyetujui melakukan persusuan oleh perempuan bukan ibu kandung sehingga Rasulullah menghindari larangan yang menjadi konsekuensi dari kebiasaan persusuan oleh perempuan yang bukan ibu kandung.

Akibat yang lahir dari saudara sepersusuan yaitu munculnya larangan dan kebolehan terkait beberapa hal. Hal yang dilarang akibat praktek sepersusuan adalah perkawinan, yaitu antara anak yang disusui dengan (ibu susu, ibu dari bapak susu, ibu dari ibu susu, saudari ibu susu, saudari bapak susu, saudari sesusuan, dan cucu dari ibu susu). Hal yang dibolehkan akibat dari praktek sepersusuan adalah bolehnya berkhlawat, dan melakukan perjalanan bersama perempuan bukan mahram. (Sayyid Sabiq, 1983) berkhalwat dibolehkan didasarkan atas hubungan sepersusuan, yaitu sepersusuan di masa kecil sehingga susu tersebut bisa mengenyangi, sebagaimana dijelaskan dalam hadis yang diriwayatkan dari Aisyah RA bahwa Nabi SAW masuk (menemui) Aisyah ketika di tempat Aisyah ada seorang laki-laki. Tampak wajah Nabi Muhammad berubah, sepertinya beliau tidak berkenan. Aisyah lalu berkata: "Dia saudaraku". Nabi Muhammad menjawab: "Lihatlah siapa yang menjadi saudaramu. Sesungguhnya persusuan itu berdampak hukum jika terjadi karena lapar.”

Hadis tersebut menyebutkan beberapa pengertian, khususnya yang terkait dengan permasalahan radha'ah. Pertama, Nabi menegaskan bahwa sepersusuan yang berdampak kepada hubungan persaudaraan adalah sepersusuan yang dilakukan ketika susu yang diminum sampai menghilangkan rasa lapar bagi bayi. Menurut Mustafa Dib al-Bigha, persusuan yang mengenyangi rasa lapar hanya terjadi pada masa susu yang membuat seseorang merasa lapar jika tidak meminumnya dan merasa kenyang jika meminumnya. Hal itu hanya 
terjadi pada masa anak masih kecil. (Mustafa Dib al-Bigha, t.th). Kedua adalah bahwa menyusui oleh orang lain selain ibu kandungnya adalah hukumnya boleh.

Kesimpulan ketiga itu bisa disimpulkan juga dari Firman Allah SWT. dalam al-Quran surat al-Talak ayat 6 , yang artinya berbunyi: Jika mereka menyusui anak-anakmu maka berikanlah mereka upah menyusui, dan musyawarahkanlah di antara kamu segala sesuatunya dengan baik. Jika kamu menemui kesulitan, perempuan lain boleh menyusui anak tersebut untukmu.

Ayat tersebut di atas menjelaskan bahwa menyusui merupakan opsional bagi ibu. Ketika ibu mau menyusui, ia wajib memperoleh upah dan nafkah dari Ayahnya, namun ketika ibu enggak mau atau ada hambatan dalam menyusui, maka bayi boleh disusui oleh perempuan yang bukan ibu kandungnya. (Abu Bakar al-Jassas, 1993)

\section{b. Hukum Muamalah: Hibah dan Jual Beli}

Akad yang sering digunakan dalam praktek bank ASI, sebagaimana terjadi di bank-bank ASI di Barat, adalah akad donor (hibah). Pendonor susu tidak menerima imbalan uang dari susu yang ia donorkan kepada bank ASI. Uang yang diberikan oleh penerima donor ASI adalah sebagai ganti biaya transportasi, biaya perawatan dan pengolahan ASI. Akan tetapi tidak tertutup kemungkinan pemberian ASI oleh perempuan lain dilakukan dengan akad muamalah lainnya, terkhususnya jual beli.

Karena itu, sebelum membahas terkait dengan hukum bank ASI perlu juga didudukkan hukum dasar hibah dan jual beli (masuk ke dalam wilayah muamalah). Dalam persoalan muamalah, berlaku kaidah-kaidah umum: yaitu segala persoalan dalam muamalah pada dasarnya adalah boleh selama tidak ada dalil yangg melarangannya. Secara khusus banyak terdapat dalil-dalil yang menjelaskan kebolehan bermuamalah jual beli dan muamalah hibah. (Mustafa Dib al-Bigha, t.th). bolehnya muamalah jual beli sebagaimana firman Allah SWT dalam alQuran surat al-Baqarah ayat 275 yang artinya: Allah menghalalkan jual beli dan mengharamkan riba. 
Kebolehan hibah juga didasarkan dalam hadis Rasulullah SAW yang diriwayatkan oleh al-Bukhari dan Muslim yang artinya: Dari Abu Hurairah RA bahwa Nabi SAW jika diberi makanan, beliau menanyakan mengenai (asal) makanan tersebut. Jika dijawab bahwa makanan itu dari hadiah, maka beliau makan. Jika dijawab berasal dari zakat, beliau tidak mau memakannya. Hadis tersebut mempertegas bahwa hibah dibolehkan dan Rasulullah sendiri menerima hibah. (Sayyid Sabiq, 1983).

\section{Hukum Bank ASI}

Jika permasalahan bank ASI dikembalikan kepada hukum dasar dari persusuan dan muamalah akan disimpulkan beberapa hukum sebagai berikut:

a. Hukum dasar muamalah adalah boleh, termasuk jual beli maupun hibah

b. Hukum dasar persusuan, yaitu ibu kandung mau menyusui atau tidak menyusui adalah dibolehkan, kalau persusuan dianggap sebagai hak opsional seorang ibu kandung dan menjadi kewajiban ayahn untuk memenuhinya baik melalui ibu kandung atau melalui perempuan lain yang bukan ibu kandungnya.

c. Persusuan terhadap seorang bayi oleh perempuan yang bukan ibu kandung hukumnya dibolehkan, sebagaimana dari penjelasan di atas.

Berdasarkan persoalan hukum dasar di atas dapat diambil intisarinya adalah bahwa seandainya tidak ada pertimbangan (qarinah) lain, hukum donor atau jual beli susu adalah mubah. Kesimpulan tersebut didasarkan pada hukum dasar jual beli dan hibah yaitu diboleh kan, dan dilandaskan atas tidak adanya rukun atau syarat yang dilanggar dalam praktek jual beli atau donor ASI. (Sayyid Sabiq, 1983).

a. Timbulnya hubungan hukum baru antara ibu susu (bukan ibu kandung) dengan anak yang disusuinya.

b. Hubungan hukum tersebut meniscayakan; pengharaman kawin antara ibu susu atau anak kandung ibu susu dengan anak susuannya dan penghalalan khalwat antara ibu susu dengan anak susu atau anak susu dengan saudara sepersusuannya.

Jurnal At-Tafkir: Volume 13 Nomor 1 Tahun 2020

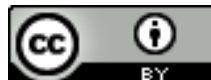

This work is licensed under a Creative Commons Attribution 4.0 International License 
Konsekuensi diatas sangat perlu mendapatkan perhatian penting, karena ajaran Islam sangat mementingkan persoalan keturunan dan kehormatan. Oleh sebab itu, salah satu tujuan penetapan syariat Islam adalah memelihara keturunan/kehormatan. Permasalahannya, dalam praktek bank ASI, sebagaimana terjadi dalam praktek Bank ASI di wilayah Barat dapat menimbulkan ketidakjelasan hubungan antara anak susu dengan ibu susu, sehingga kemungkinan terjadinya perkawinan antara anak susu dengan anak kandung ibu susu bisa terjadi. Bila hal itu sampai terjadi, maka pernikahannya menjadi tidak sah (batal).

Persoalan akan muncul ketika bank ASI membuka pintu terjadinya percampuran susu ataU ketidakjelasan hubungan persusuan tersebut. Pertanyaannya adalah bagaimana jika terjadi percampuran susu dan apa konsekuensi hukumnya. Dalam menilai status hukum bank ASI, sebaiknya melihat keputusan terhadap permasalahan sejenis dalam kebiasaan fikih Islam (yurisprudensi). Hal tersebut berguna untuk memberikan bahan pertimbangan dalam membuat keputusan hukum terkait bank ASI. Pertanyaan mengenai percampuran susu tersebut telah melahirkan pembahasan di kalangan ulama. Salah satu kasus adalah sebagaimana dikemukakan oleh Ibnu Qudamah dalam alMughni, yaitu mengenai kasus persusuan oleh umm al-walad. (Umm al-walad adalah budak perempuan yang melahirkan anak dari majikannya).

Jika seorang laki-laki memiliki lima umm al-walad yang kelimanya memiliki susu, kemudian ada anak yang menyusu masing-masing satu kali susuan kepada lima umm alwalad tersebut, maka para umm al-walad tersebut tidak menjadi ibu mereka. Namun majikan mereka menjadi ayah bagi anak tersebut. Ini adalah pendapat Ibn Hamid dengan alasan anak itu menyusu dari susu milik majikan tersebut lima kali. Ada pendapat lain yang tidak menegaskan hubungan bapakanak karena persusuan yang terjadi adalah persusuan yang tidak melahirkan hubungan ibu-anak sehingga tidak melahirkan hubungan bapak-anak. (Ibn Qudamah, 1994).

Dalam kasus di atas Ibnu Qudamah mentarjih pendapat pertama. Jadi, percampuran susu menurut Ibn Qudamah tidak melahirkan hubungan ibu dan Jurnal At-Tafkir: Volume 13 Nomor 1 Tahun 2020

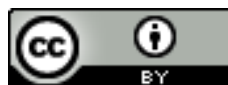

This work is licensed under a Creative Commons Attribution 4.0 International License 
anak ketika kurang dari lima susuan. Mafhumnya adalah bahwa percampuran susu melahirkan konsekuensi hukum jika lebih dari lima susuan, meskipun telah mengalami percampuran susu. Mafhum itu kemudian ditegaskan oleh Ibnu Qudamah sendiri dalam kasus pencampuran susu antara beberapa wanita untuk diberikan kepada seorang anak. Menurutnya, pencampuran demikian konsekuensi hukumnya sama dengan meminum dari satu per satu perempuan, yaitu menimbulkan pengharaman sebagaimana haramnya nasab. Hal itu ia analogkan dengan percampuran susu dengan benda lain, seperti susu atau air, yang tetap menimbulkan konsekuensi hukum pengharaman. (Ibn Qudamah, 1994).

Kesimpulannya, praktek bank ASI merupakan praktek penyaluran susu dari ibu donor kepada anak yang membutuhkan ASI, biasanya melalui akad hibah, baik secara tidak langsung ataupun melalui perantara. Pada dasarnya, memberikan susu kepada anak orang lain atau hibah adalah perbuatan yang dibolehkan dalam Islam. Ketika ASI tersebut diminum oleh anak yang berusia kurang dari dua tahun, maka ASI tersebut melahirkan hubungan hukum, baik ASI tersebut bercampur dengan susu dari banyak perempuan/ibu susu maupun dari satu perempuan/ibu susu saja. Hubungan hukum yang lahir adalah terjadinya larangan pernikahan sebagaimana larangan untuk menikahi saudara berdasarkan hubungan nasab.

\section{Tinjauan ASI dalam Ilmu Kesehatan}

ASI memiliki kandungan gizi yang beragam dan lengkap. Hal yang sangat penting pada ASI adalah segala kandungannya sesuai keadaan bayi dan bersifat alami, bukan hasil sintetik sehingga aman dan sangat bermanfaat bagi bayi. Rina Werdayanti, 2015) Komponen dari ASI juga telah memenuhi kebutuhan bayi baik dari perkembangan ASI yang disesuaikan dengan kebutuhan nutrisi bayi, kandungan enzim yang mudah untuk dicerna, suhu ASI yang berharmonisasi sempurna dengan suhu bayi, dan kandungan antibodi yang dapat mencegah bayi dari penyakit. (Ahmad Yusuf Al-Hajj, 2016). 
إن

a) Macam-macam ASI

1) Kolostrum

Kolostrum merupakan ASI yang diproduksi di hari-hari pertama dan biasanya selama empat hari. Kolostrum mempuyai warna kekuningan yang dapat diproduksi 150-300 ml atau 7,5 sendok teh per 24 jam. Pada minngu pertama bayi bisa menyusu sebanyak 1,4 sendok teh. Bayi perlu sering menyusu langsung untuk merangsang produksi ASI selanjutnya. (Rina Werdayanti, 2015)

2) ASI Transisi

ASI transisi merupakan ASI yang keluar setelah kolostrum, dan biasa diproduksi hari ke 4-10 setelah melahirkan. Pada ASI transisi ini mulai terjadi perubahan komposisi dari kolostrum ke ASI transisi yang mengakibatkan kadar protein dan immunoglobulin berkurang, kadar lemak dan karbohidrat meningkat, volume meningkat dibanding kolostrum, ASI diproduksi sebanyak ASI yang dikeluarkan meskipun belum sesuai. (Rina Werdayanti, 2015)

3) ASI Mature

ASI mature berwarna putih kekuningan yang diproduksi setelah hari ke 10 sampai akhir masa laktasi atau penyapihan nanti. Memiliki volume 300$850 \mathrm{ml}$ per 24 jam. ASI matur terus berubah sesuai pada perkembangan bayi. Pada malam hari, ASI ini lebih banyak mengandung lemak yang membantu meningkatkan berat badan dan perkembanagan otak yang maksimal. (Rina Werdayanti, 2015)

\section{b) Rincian zat ASI}

Keluarnya ASI yang akan dihasilkan oleh seorang ibu tidak bergantung pada besarnya payudara ibu, tetapi lebih berpengaruh pada makanan yang bergizi yang dimakan selama masa hamil dan masa menyusui. Jadi hal ini tidak berpengaruh pada produksi ASI selama asupan makanan dikonsumsi dengan baik, tetapi selain dari pada makanan yang baik kondisi psikologi juga berperan penting dalam banyaknya produksi ASI. Kandungan utama ASI, sebanyak 88\% adalah air. Jumlah ini cukup memenuhi kebutuhan cairan. Air juga berfungsi 
membuang kelebihan zat terlarut. Sisanya ASI terdiri karbohidrat, protein, lemak, vitamin, mineral, enzim, hormon, dan faktor pertumbuhan. (Rina Werdayanti, 2015)

\section{c) Manfaat ASI}

Sacara ringkas manfaat-manfaat menyusui sebagai berikut (Diah Hartati, 2011):

1) Menyusui memberikan banyak manfaat psikis kepada si anak karena ia merasakan hangatnya kasih saying ibu ketika menyusu. Adapun anak-anak yang tidak mendapatkan penyusuan ibu secara baik lebih rentan terkena gangguan psikis dan perilaku. Persentase perilaku menyimpang dalam batasbatas tertentu memiliki kaitan dengan sejarah masa kecilnya yang tidak mendapatkan penyusuan ibunya. (Perpustakaan Nasional RI, 2013)

2) Interaksi ibu-bayi dan kandungan nilai gizi ASI sangat dibutuhkan untuk perkembangan system syaraf otak yang dapat meningkatkan kecerdasan bayi. Karena berdasarkan hasil penelitian, anak yang mengkonsumsi ASI hanya dalam waktu 12 bulan memiliki rata-rata IQ 5,9. Selain itu, sebuah penelitian yang dilakukan peneliti asal Inggris terhadap 9000 anak yang berumur 5-10 tahun ditemukan bahwa anak-anak yang tidak mendapatkan ASI serta berasal dari orang tua yang bercerai atau berpisah, memiliki resiko mengalami kecemasan yang berlebihan 9,4 kali lebih banyak dibandingkan anak lainnya. Sedangkan anak-anak dari orang tua yang bercerai namun mengonsumsi ASI saat bayi hanya memiliki risiko mengalami kecemasan yang berlebihan sebanyak 2,2 kali dibandingkan yang pertama. (Yusuf Hanafi, 2012)

3) Dengan menyusui ibu dapat cepat dalam kondisi pulih.

Adapun manfaat dari aspek psikologik, diantaranya: interaksi Ibu dan Bayi: Pertumbuhan dan perkembangan psikologik bayi tergantung pada kesatuan ibu-bayi tersebut, dan pengaruh kontak langsung ibu-bayi, dimana ikatan kasih sayang ibu bayi terjadi karena berbagai rangsangan seperti sentuhan kulit (skin to skin contact). Bayi akan merasa aman dan puas karena bayi merasakan kehangatan 
tubuh ibu dan mendengar denyut jantung ibu yang sudah dikenal sejak bayi masih dalam Rahim.

\section{Pandangan Ulama Tentang Bank ASI}

\section{Pendapat Ulama yang Membenarkan Adanya Bank ASI}

Alasan ulama kontemporer yang membenarkan Bank ASI adalah karena Bayi yang meminum ASI dari bank ASI tidak bisa menjadi mahram bagi wanita yang mempunyai ASI tersebut, karena sesusuan yang mengharamkan adalah jika bayi menyusu langsung menghisap puting payudara perempuan yang mempunyai ASI, sebagaimana seorang bayi yang menyusu pada ibu kandungnya.

Sedangkan praktek pada bank ASI, sang bayi hanya meminum ASI yang sudah dikemas atau tidak langsung menghisap puting payudara perempuan tersebut. Ulama besar setenar Prof. Dr. Yusuf Al-Qardhawi mengatakan bahwa dia tidak menjumpai alasan-alasan untuk melarang keberadaan "Bank ASI." Asalkan bertujuan untuk mewujudkan kemashlahatan yang kuat dan untuk memenuhi keperluan yang wajib dipenuhi. Yusuf Al-Qardhawi cenderung mengatakan bahwa bank ASI bertujuan mulia dan baik, didukung oleh Islam untuk memberikan bantuan kepada semua yang membutuhkan, apa pun sebab kelemahannya. Lebih-lebih bila yang bersangkutan adalah bayi yang baru dilahirkan yang tidak mempunyai daya dan kekuatan. (Irmawati, 2019)

Sejalan dengan pendapat Yusuf Al-Qardhawi, ada juga pendapat lainnya yang membolehkan keberadaan Bank ASI jika telah terpenuhi syarat-syarat yang sangat ketat, di antaranya: Semua ASI yang terkumpul di Bank ASI, harus disimpan di tempat yang khusus dengan memperjelas identitas pemiliknya dan dipisahkan dari ASI-ASI yang lain. Dan setiap bayi yang meminum ASI tersebut harus didata juga dan harus dinformasikan kepada pemilik ASI tersebut, supaya jelas nasabnya. Dengan demikian, kemungkinan terjadinya percampuran nasab yang dikhawatirkan oleh para ulama yang melarang bisa dihindari. Prof. DR. Ali Mustafa Ya'qub, MA., salah seorang Ketua MUI Pusat menjelaskan bahwa tidak ada larangan untuk mendirikan Bank ASI dan Donor ASI selama hal tersebut dibutuhkan untuk kelangsungan hidup anak manusia. "Hanya saja syara' 


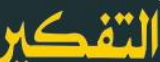

mengatur, jika si ibu bayi tidak dapat mengeluarkan air susu atau dalam situasi lain ibu si bayi meninggal maka si bayi harus dicarikan ibu susu.

Tidak ada sejaqrah dalam Islam dalam situasi tersebut mencari solusi mencarikan susu sapi sebagai pengganti, kendatipun zaman nabi memang tidak ada susu formula tapi susu kambing dan sapi sudah ada. Ini berarti bahwa mendirikan Bank ASI dan mendonor ASI boleh-boleh saja karena memang Islam tidak mentoleransi susu yang lain selain susu Ibu sebagai susu pengganti dari susu ibu kandungnya. Hanya saja pencatatannya harus benar dan kedua keluarga harus dipertemukan serta diberikan sertifikat. Karena 5 kali meminum susu dari ibu menyebabkan menjadi mahramnya si anak dengan keluarga si ibu susu. Artinya anak mereka tidak boleh menikah.

\section{Pendapat Ulama yang tidak Membenarkan Bank ASI}

Alasan sebagian para ulama tidak membenarkan Bank ASI adalah karena Bank ASI akan menyebabkan bercampurnya nasab, karena sesusuan yang mengharamkan bisa terjadi dengan masuknya susu ke dalam perut bayi tersebut, walaupun tanpa harus dilakukan penyusuan langsung menghisap di puting payudara, sebagaimana seorang ibu yang menyusui anaknya. Di antara ulama kontemporer yang tidak membenarkan adanya Bank ASI adalah Prof. Dr. Wahbah Az-Zuhayli. Dalam kitab Fatawa Mu'ashirah, beliau menyebutkan bahwa mewujudkan institusi bank susu tidak dibolehkan dari segi syariah. Demikian juga dengan Majma' al-Fiqih al-Islamiy melalui Badan Muktamar Islam yang diadakan di Jeddah pada tanggal 22-28 Desember 1985 M./10-16 Rabiul Akhir 1406 H. Lembaga ini dalam keputusannya (qarar) menentang keberadaan bank air susu ibu di seluruh negara Islam serta mengharamkan pengambilan susu dari bank tersebut.

Kesimpulan yang bisa disarikan dari Fatwa Majma' al-Fiqih al-Islamiy adalah sebagai berikut ini:

1. Bank ASI telah diuji cobakan di masyarakat barat. Namun muncul beberapa hal negatif, dari sisi teknis dan ilmiah dalam uji coba ini, sehingga mengalami penyusutan dan kurang mendapatkan perhatian;

Jurnal At-Tafkir: Volume 13 Nomor 1 Tahun 2020

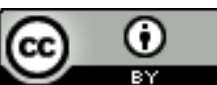

This work is licensed under a Creative Commons Attribution 4.0 International License 


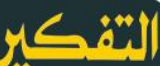

2. Syariat islam menjadikan hubungan persusuan sebagaimana hubungan nasab. Orang bisa menjadi mahram dengan persusuan sebagaimana status mahram karena hubungan nasab, dengan sepakat ulama. Kemudian, diantara tujuan syariah adalah menjaga nasab. Sementara bank ASI menyebabkan tercampurnya nasab atau menimbulkan banyak keraguan nasab;

3. Interaksi sosial di masyarakat Islam masih memungkinkan untuk mempersusukan anak kepada wanita lain secara alami. Keadaan ini menunjukkan tidak perlunya Bank ASI.

Berdasarkan kesimpulan di atas maka diputuskan dilarangnya keberadaan Bank ASI untuk para Ibu-ibu di tengah masyarakat Islam, Haramnya memberikan susu dari Bank ASI. Itulah beberapa alasan ulama yang menolak keberadaan bank ASI.

\section{KESIMPULAN}

Bank ASI adalah tempat pengumpulan, penyimpanan ASI dari donor ASI yang kemudian akan berikan kepada ibu-ibu yang tidak bisa memberikan ASI nya sendiri kepada bayinya. Terkait dengan keberadaan bank ASI tersebut melahirkan hukum yang diperdebatkan di kalangan ulama kontemporer.

Ada sebagian ulama membolehkan Bank ASI dengan alasan Bayi yang meminum ASI dari bank ASI tidak bisa menjadi mahram terhadap perempuan yang mempunyai ASI tersebut, karena sesusuan yang diharmkan dalam Islam adalah jika dia menyusu langsung dengan menghisap puting payudara perempuan yang memiliki ASI, sebagaimana seorang bayi yang menyusu pada ibunya. Sedangkan dalam praktek bank ASI, sang bayi hanya meminum ASI yang sudah dikemas (bukan menghisap langsung pada puting payudara). Dan ada pendapat lainnya yang menyatakan bahwa Bank ASI dibolehkan jika telah memenuhi beberapa syarat yang sangat ketat, dan setiap bayi yang meminum ASI tersebut harus didata juga dan diberitahukan kepada pemilik ASI tersebut, supaya jelas nasabnya.

Berbeda pendapat dengan sebagian ulama yang mengharamkan keberadaan bank ASI dengan alasan bahwa praktek Bank ASI tersebut akan 


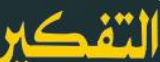

menyebabkan bercampurnya nasab, karena susuan yang mengharamkan bisa terjadi dengan sampainya susu ke dalam perut bayi tersebut, walaupun tanpa harus menghisap lansung pada puting payudara ibu susu, seperti halnya seorang ibu yang menyusui anaknya. Di antara ulama kontemporer yang tidak membenarkan adanya Bank ASI adalah Prof. Dr. Wahbah Az-Zuhayli. Dalam kitab Fatawa Mu'ashirah, beliau mengatakan bahwa mewujudkan institusi bank susu dilarang dari segi syariah Islam. Demikian juga dengan Majma' al-Fiqih alIslamiy melalui Badan Muktamar Islam yang diadakan di Jeddah pada tanggal 2228 Desember 1985 M./10-16 Rabiul Akhir 1406 H. Lembaga ini dalam keputusannya (qarar) melarang keberadaan bank air susu ibu di seluruh negara Islam serta melarang pengambilan susu dari bank ASI tersebut.

\section{DAFTAR PUSTAKA}

Abdurrahman al-Jazary.(2001). Kitab al-Fiqh ala Madhahib al-Arba'ah. Beirut: Dar Ibn Hazm.

Abu al-Faraj Jamal al-Din al-Jawzi. (1994), Zad al-Masir fi Ilm al-Tafsir, Juz I, Beirut: Dar al-Kutub al-Ilmiyyah.

Abu Bakar al-Jassas. (1993). Ahkam al-Quran, Juz I, Beirut: Dar al-Fikr.

Abu Zakariyya Yahya al-Nawawi. (tt.). Rawdlah al-Talibin, Jilid VI. Beirut: Dar alKutub al-Ilmiyyah.

Ahmad Yusuf Al-Hajj. (2016). Mukjizat Al-Qur'an yang Tak Terbantahkan, Solo: Aqwam.

Ali Hasan. (1997). Masail Fiqhiyah Al Haditsah, Jakarta: PT. Raja Grafindo Persada.

Anne Hagen Grøvslien and Morten Grønn. (2009). "Donor Milk Banking and Breastfeeding in Norway." Journal of Human Lactation. J. Hum Lact. 25.

Cholil Uman. (2000). Agama Menjawab Tentang Berbagai Masalah Abad Modern, Jakarta: PT. Raja Grafindo Persada.

Diah Hartati. (2011). Buku Serba Tahu Kehamilan Persalinan e Perawatan Bayi, Yogyakarta: Citra Media.

Ibn Qudamah. (1994). Al-Mughni ala Muktashar al-Khiraqi, Juz VII, Beirut: Dar alKutub al-Ilmiyyah.

Imad Zaki Al-Barudi. (tt.). Tafsir Quran Wanita, Jakarta: Pena Pundi aksara, t.t.

Jalal al-Din al-Suyuthi, (tt.). Muntaqa al-Yunbu' fi ma Zada 'ala al-Rawdlah min al-Furu'.

Dicetak bersama Rwadlah al-Talibin li al-Nawawi. Jilid VI. Beirut: Dar alKutub al-Ilmiyyah.

Mahjuddin. (2003). Masailul Fiqhiyah: Berbagai Kasus yang Dihadapi Hukum Islam Masa Kini, Cet. V, Jakarta: Kalam Mulia. 
Masjfuk Zuhdi. (2000). Masail Fiqhiyah: Kapita Selekta Hukum Islam, Cet. XI, Jakarta: PT. Raja Grafindo Persada.

Muhammad bin Ali al-Syawkani. (1994). Fath al-Qadir, Juz I, Beirut: Dar al-Kutub al-Ilmiyyah.

Muhammad bin Ismail al-Kahlani al-Shan'ani. (tt.). Subul al-Salam, Juz III, Jilid II., Semarang: Toha Putera.

Mustafa Dib al-Bigha. (tt.). Al-Tadzhib fi Adillah Matn al-Ghayah wa al-Taqrib, Surabaya: al-Haramain.

Perpustakaan Nasional RI. (2013). Ensiklopedia Pengetahuan Al-Qur'an dan Hadis, Jakarta, Kamil Pustaka: 2013.

Rina Werdayanti. (2015). Bapak ASI dan Ibu Bekerja Menyusui, Yogyakarta: Familia.

Sayyid Sabiq. (1983). Fikih Sunnah, Jilid III. Beirut: Dar al-Fikr,1983.

Taqi al-Din al-Husayni. (tt.). Kifayah al-Akhyar fi Hall Ghayah al-Ikhtishar, Juz II. Surabaya: al-Hidayah.

Yusuf Hanafi. (2010). Peningkatan Kecerdasan Anak Melalui Pemberian ASI dalam AlQur'an, Mutawâtir: Jurnal Keilmuan Tafsir Hadis Volume 2, Nomor 1, Juni. 